\title{
AN AMBITION ANAL YSIS REPRESENTED BY THE MAIN CHARACTER IN PERFUME: THE STORY OF A MURDERER
}

\author{
Relita Moputi ${ }^{1}$ \\ Dahlia Husain ${ }^{2}$ \\ Englsih Literature Department, Faculty of Cultural Science, Muhammadiyah \\ University of Gorontalo \\ relita02@gmail.com
}

\begin{abstract}
Literary works are the reflection of real life. Movie is a literary work that tells a story by using some conflict. The character in a movie usually describes the human psychology and behavior. Ambition is one of human psychology. This research discusses about the ambition of the main characters in Perfume: the Story of a Murderer. This movie tells about the ambitious the main character to make a perfume by killed 26 victims. He has an ambition to fulfill their psychogenic needs. The fulfillment of psychogenic needs that is experienced by the main character on the movie is analyzed in Henry Murray's The Need Theory of Personality. This research is conducted by using the qualitative method. This research uses psychological approach to analyze the fictitious of the main character. The result from this study is that the ambition has the causes and the effects.
\end{abstract}

Keywords: Movie, Psychogenic needs, Ambition, Psychological Approach.

\section{INTRODUCTION}

Literature is the imaginative work that pictures the human life in society which can be enjoyed, understandable, and used by the society also. There are many kinds of literature usually called genre. Genre of literature is not only indicating the name. Farther, the convention is used by the people to the literary work producing the characteristics of each literary works. The author will write the result of this imagination in a form of literary works.

According to Pickering \& Hoeper (1981) literature is a uniquely human activity, born of man's timeless desire to understand, express, and finally share experiences. In literature, there are poetry, novel, drama, theatre, movie etc. as the branch of literature itself. Everyone can create a literary work with their own writing style, and their imagination too. A literary work is able to make writers have a place to pour anxiety, happiness, sadness, or other life experiences into a literary work that is certainly unique. 
A psychological is an important thing, and also psychological problem is an interesting thing when we try to analyze it more. Psychology can be defined as a science of physic. The definitions of psychology come from many experts stating that there is a relation between behavior and psychological human. So that psychology can be explained as the science focuses on human behavior as the psychological representation of human soul. Wellek and Warren (1989) explain that psychology of literature can be used to analyze some studies. For the first, psychology of literature may be used to investigate the author as a human being. Secondly, study of creative process in creating literature is also can be consideration as a research of psychology of literature. Some theories of psychology can be used to analyze the main character in a literary work. Ambition is one of human attitude. This is included in a psychological problems and this research discusses about the ambition of the main characters in Perfume: the Story of a Murderer movie.

According to Pradopo (1994: 26) the literary work is as the picture of the world and human life, the main criteria that is putted on the literary work is 'truth', or everything that wants to be pictured by the author. Through that process, the reader of their literary work will be able to catch the characteristic of the author related with the world around him/her. Literature introduces us to new worlds of experience means that the literary work is an immediate part of the literary environment, the aggregate of all the socially active literary works of a given epoch and social group. From a strictly historical point of view the individual literary work is a dependent and therefore actually inseparable element of the literary environment (Morris, 2005).

Film and literature are two different things with a similar goal to create sublimity in human imagination and understanding. Both film and literature work hand in hand to boost the progress of human civilization. And they are the complimentary in nature and one is no substitute to the other, like letters and sounds in human communication. Film and literature 
inspire and enrich each others. Film and literature are common in certain points of contact, as they are the narrative structure and impression of reality. No doubt, literature and film are the artistic expression, unifying the human mind. Most of the films are adaptations of novels because of the conflict on that novel can make the reader feel the same way. According to Wellek and Warren (1993) they state that the conflict is something dramatic, inexpediency perception between two people in a story.

In 1930, Murray coined the term personology to describe the branch the science of psychology that studies human life and its influencing factors his journey. Murray believes strongly that to understand the meaning of any one process from personality, a person must have an understanding of the whole. Theories of personality based on needs and motives suggest that our personalities are a reflection of behaviors controlled by needs. While some needs are temporary and changing, other needs are more deeply seated in our nature. According to Murray, these psychogenic needs function mostly on the unconscious level but play a major role in our personality. Murray identified needs as one of two types: Primary Needs (viscerogenic need) and Secondary Needs (psychogenic need).

Ambition is a desire or passion that is passionate to get what we want, such as the desire of someone who is great to achieve something in his life or do something to achieve good goals with his desires then it is called with ambition. According to Murray (1938) ambition needs are related to the need for achievement,exhibition and recognition. The need for achievement is often expressed by succeeding, achieving goals, and overcoming obstacles. The need for recognition is met by gaining social status and displaying achievements. These needs are included in psychogenic need. Sometimes the ambition needs even involve a need for exhibition or the desire to shock and thrill other people. It is not supposed that they are fundamental, biological drives, though some may be innate (Murray, 1938).

\section{British, Jurnal Bahasa dan Sastra Inggris}


Need of Exhibition according to Murray (1938) is a need that usually related with looking for praise, appreciation, attention. To impress others through one's actions and words, even if these are shocking. This need is usually done when a person feels he has talent that can be proud of to show others. Usually, this is also done to get something they want to satisfy the desires that exist in humans. This can also be analyzed in psychology because it is closely related to the basic nature in humans. This also usually called as Obtrusiveness that is to make an impression, to be seen and heard by others. Exhibition is usually to arouse passion, be seen in awe, admired by others, entertained, surprised, aroused interest, attracted attention, or captivated. Murray believes that people have a need for what he referred to as exposition, or the desire to share what they have learned with other people.

Need of Recognition must be distinguished from need of achievement which shows behavior to do something because, because this (need of recognition) is only aims to get other people to pay attentions. This is also called as a need to accentuate our self just like the exhibition and describe people who: like to show off one's own strengths, want to be the center of attention, like to test the veracity of opinions, likes to get along, joking and adventurous and also person who like to comment on other people as statements himself capable. Based on the nature that exists in every human being, everyone naturally wants to listen to good comments for themselves.

In addition, Murray (1938) developed a theory of personality that was organized in terms of motives, presses, and needs. Murray described needs as a "potentiality or readiness to respond in a certain way under certain given circumstances" (1938).

Need of Achievement based on Murray's (1938) theory is that; work towards a goal with energy, endurance and certainty of purpose. Set high standards of behavior for yourself and work independently to achieve that standard. Overcome obstacles or master situations, manipulate objects or people. Complete a job in a sustainable manner. Be ambitious, competitive 
and full of inspiration. This need is usually describe an individual desire to progress, achieve the highest achievements, wants to always succeed through your own efforts, like a job that contains challenges, the desire to solve difficult problems and the desire to be more compared to others.

\section{RESEARCH METHOD}

The researcher used qualitative descriptive method in conducting this research. This is one of some methods of analyzing data in literary criticism. Endraswara (2013, p. 176) argues that data is the main aspect of this method. A researcher has to present the data as complete as possible and provide sufficient analysis. Quality of the depends research depends on the completeness of the data. Although interpretation. This is different with hermeneutic method for example, where it puts more emphasis in the interpretation of the data.

The technique of collecting data in this research is using a documentation method based on the transcript and also taken from some sources. Documentation is used as the technique of collecting the data in this research. According to guba and lincoln in maleong (2016, p. 217), this technique includes the use of document for research purpose. Furthermore Moleong (2016) argues that documentis all the written material which usually consist of personal documents and official documents. In this research, the researcher gathered all necessary data which related to the research by doing several steps. The first step is the researcher selected the Movie: "Perfume: story of a murderer, second step is the researcher collected the data which concern about literature and psychological approach.

According to Miles and Huberman in Sahid (2011), ), the technique of analyzing data through three (3) important stages, as follow as; (1)Data reduction; this stages refers to the process whereby the mass of qualitative data that a researcher have gathered is reduced and organized. A researcher for example must remove the irrelevant data by choosing " Perfume: story of a murderer. (2)Data display; this is the further step after doing data reduction

\section{British, Jurnal Bahasa dan Sastra Inggris}


whereby a researcher interpreted and described the data by paraphrasing and explicating the data, then analyzing the data by applying related approach. (3)Conclussion; drawing/verification; this is the stage of conclusion drawing and data ferification. On this stage, the researcher verified by elaborating the data theory of Handry Murray Theory of personality, then drew the conclusion as the result of the research.

This research uses the psychological approach as the base of research. In psychological analysis, writers are only able to see the symptoms that appear in a character described by the author, not the soul as the soul itself is abstract. Therefore psychology in literature will place literary works as dynamic phenomena, this actually causes problems in literary psychology because psychological phenomena cannot be considered as something definite meaning the symptoms that appear are only effects not the substance of the soul itself, moreover the effects psychiatric is not impossible to be engineered or made for just a sensation. Although not all are engineered, it is not uncommon to find someone who tries to appear in a different form and display different characters before the public only for a certain purpose.

According to Whitehead (2016), the more appropriate way to pursue psychological literary criticism would be to understand an author's implicit, informal personality theory, match it to the explicit formal theory with which it is most congruent, and then use that personality theory systematically as a lens through which to view the author's work. All of psychologists share a belief in the observational methods of science as the foundation of psychological research.

\section{RESEARCH FINDING AND DISCUSSION}

The writer concluded that there are some needs in psychogenic needs according to Murray (1938) which are used to apply in this analysis. Such as the need of acquisition, need of exhibition, the need of recognition, and need of achievement. These needs are needed in this analysis because they related 
with the ambition in human life. This is also has a close relation with the main characters' ambition in this analysis.

Ambition is a desire or passion that is passionate to get what we want, such as the desire of someone who is great to achieve something in his life or do something to achieve good goals with his desires then it is called with ambition. According to Murray (1938) ambition needs are related to the need for achievement and recognition. The need for achievement is often expressed by succeeding, achieving goals, and overcoming obstacles. The need for recognition is met by gaining social status and displaying achievements. Sometimes the ambition needs even involve a need for exhibition or the desire to shock and thrill other people. These needs are included in psychogenic need.

Baldini : No! You shall not! You may fill this one. Grenouille : Yes, Master. But, Master Baldini... You must let me do it in my own way.

Baldini : As you please. No! Don't drop it. That's pure alcohol. You want to blow up the building? You have to measure it first! (in minutes: 39:05)

The data shows us the ambition in a perfume movie serves to provide its own satisfaction with the main character itself. Writers analyzed that Grenouille felt able to make a perfume he had never made before. At this spart, Grenouille still used his ability to provide his own satisfaction. According to Murray's concept of pressure represents the environmental determinants of behavior. A pressure is another person's attribute or property of an object or an environmental condition which helps or holds one's progress towards a certain goal. Murray (1938) state that; "an object's pressure is what it can do to the subject or to the subject - the power he has to influence the happiness of the subject in one way or another more". All needs interact with one another in a variety of ways. Certain needs demand satisfaction before others. The idea of abatement tension and then test the concept of needs, of course the concept of motivation the most influential and the only one that represents internal motivation essential.

\section{British, Jurnal Bahasa dan Sastra Inggris}


Therefore, in the above data the researcher concludes that the data can be categorized as psychogenic needs - Need of Exhibition. This can be proven by the scenes performed by the main character to prove his ability to make perfume, and also this can satisfy the main character himself.

\section{Grenouille : You have to teach me that!}

Baldini : All right. Calm down, my boy. Calm down. We have work to do.

Grenouille: "The soul of beings is their scent." You said that, master.

Baldini : Did I?

Grenouille : I will make you as many perfumes as you want but you have to teach me how to capture the smell of all things. Can you do that?

Baldini : Well, naturally. Then teach me everything you know and I'll make you the best perfume in the whole world.

(in minutes: 48:58)

Being someone who has talent, makes Grenouille feel must do something with that talent. And, after traveling from one place to another, he finally discovered and collected many different smells from different places. In this case, he also became increasingly obsessed with these odors. He felt his own satisfaction when he smelled the odors he had just discovered.

Therefore, Grenouille was increasingly obsessed. And, his obsession began when he accidentally smelled a smell that was truly fragrant and he liked. He just wants to catch the smell. He did not want the smell to disappear. This can also be proven in sentences; "... but you have to teach me how to capture the smell of all things".

In the data above, the writers concluded that, truly obsessed and ambitious to make perfume and ambition at that time only so that he felt satisfied when he was able to show the world the talent he had.

Grenouille: It's all done.

Baldini: : This is Amor \& Psyche!

Grenouille: But it's not a good perfume, Master. If you let me again, Master, I'll make it more better. Now it's a really good perfume. Don't you want to smell it, Master?

\section{British, Jurnal Bahasa dan Sastra Inggris}


(in minutes: 41:47)

Grenouille is a hardworking man. The data above shows that Grenouille will always try to do the best so that he can continue to survive. In the data above, Baldini as a businessman and maker of perfume felt rivaled and curious about the perfume called Amor \& Psyche. Therefore, Baldini tried to find out the perfume formula by examining the smell. However, he still could not find a suitable odor and formula. He felt that the Amor \& Psyche perfume currently available was fake. Therefore, Baldini was very satisfied with Amor \& Psyche made by Grenouille.

Grenouille who has had a natural talent since he was born was always able to stand alone just by relying on his abilities. Even without learning various formulas in his previous life, he was still able to create something extraordinary. And making Amor \& Psyche perfume was Grenouille's first achievement in his life. Because before he was only able to smell without making it now he was finally given the opportunity to prove his ability without learning the formula and only rely on his smell.

According in Murray (1951) theory, the most important thing to find about someone is overall directionality or goal orientation of one's activities whether it is internal as in the mind or externally as in physical words and actions. The thing that relating to this goal has led Murray to develop a system of constructs very carefully designed motivation. Although the trend in psychology is to use a minimum number of concepts in explain motivation (in the Adler system, for example, seeking superiority is the only one motives that embrace it all), Murray has said emphatically that complexity human motives make us consider a large number of variables. His business for provide empirical definitions of these variables beyond other efforts in motivation area.

In this case, Grenouille increasingly found a way to his ambition. $\mathrm{He}$ really has the ambition to create the best perfume that has never before existed in this world. He tried hard to convince Baldini of his ability to make perfume. Grenouille even promised Baldini to make him the best 
perfume and more, provided that Baldini would let Grenouille work for himself in creating a new recipe or formula that would certainly had a benefit for Baldini.

Madam : Morning. Why have you covered the tank?

Grenouille : It's an experiment, Madame. To protect the

blossoms from daylight. To preserve the scent better.

Madam : Well, if you say so. Come with me. I'll settle your

master's account.

(in minutes: 01:15:14)

In the data above, Grenouille is conducting an experiment. After repeatedly failing to collect odors to make perfume by killing his victims, Grenouille finally succeeded in conducting his experiments. Therefore the writer concludes that the above data can also be categorized in the need of achievement, because at that time he had succeeded and almost reached his obsession in collecting 26 odors from the victims of the virgin women he had killed at that time.

To fulfill his need of achievement, Grenouille finally had to do a lot of killing. This was done so that the perfume of his dreams which had been his obsession could be fulfilled. According to Murray (1938) which are used to apply in the analysis. Such as the need of acquisition, need of exhibition, the need of recognition, and need of achievement. These needs are needed in this analysis because they have a close relation with the main character' ambition in his life.

Grenouille: It's all done.

Baldini: : This is Amor \& Psyche!

Grenouille: But it's not a good perfume, Master. If you let me again, Master, I'll make it more better. Now it's a really good perfume. Don't you want to smell it, Master?

(in minutes: 41:47)

Grenouille is a hardworking man. The data above shows that Grenouille will always try to do the best so that he can continue to survive. In the data above, Baldini as a businessman and maker of perfume felt rivaled and curious about the perfume called Amor \& Psyche. Therefore, Baldini tried to find out the perfume formula by examining the smell. 
However, he still could not find a suitable odor and formula. He felt that the Amor \& Psyche perfume currently available was fake. Therefore, Baldini was very satisfied with Amor \& Psyche made by Grenouille.

Grenouille who has had a natural talent since he was born was always able to stand alone just by relying on his abilities. Even without learning various formulas in his previous life, he was still able to create something extraordinary. And making Amor \& Psyche perfume was Grenouille's first achievement in his life. Because before he was only able to smell without making it now he was finally given the opportunity to prove his ability without learning the formula and only rely on his smell.

According in Murray (1951) theory, the most important thing to find about someone is overall directionality or goal orientation of one's activities whether it is internal as in the mind or externally as in physical words and actions. The thing that relating to this goal has led Murray to develop a system of constructs very carefully designed motivation. Although the trend in psychology is to use a minimum number of concepts in explain motivation (in the Adler system, for example, seeking superiority is the only one motives that embrace it all), Murray has said emphatically that complexity human motives make us consider a large number of variables. His business for provide empirical definitions of these variables beyond other efforts in motivation area.

In this case, Grenouille increasingly found a way to his ambition. $\mathrm{He}$ really has the ambition to create the best perfume that has never before existed in this world. He tried hard to convince Baldini of his ability to make perfume. Grenouille even promised Baldini to make him the best perfume and more, provided that Baldini would let Grenouille work for himself in creating a new recipe or formula that would certainly had a benefit for Baldini.

The people of Grasse awoke to a terrible hangover. For many of them, the experience was so ghastly, so completely inexplicable and incompatible with their morals that they literally erased it from their memories. The town council was

\section{British, Jurnal Bahasa dan Sastra Inggris}


in session by the afternoon and an order was passed to the police lieutenant to immediately begin fresh investigations into the murders. The following day, Dominique Druot was arrested. It was in his back yard that they found the hair of the victims.

(in minutes: 02:12:12)

The data above shows the achievements made by Grenouille due to his ambitions. He has succeeded in making the people of Grasse submit to him even a man who is so vengeful of himself is also subject to him.

Based on the pieces of data above, this proves that Grenouille has succeeded in fulfilling one of his psychogenic needs, namely achievement need. The data showed Grenouille, who was no longer accused of being a murder suspect of 26 women at Grasse at the time. Grenouille managed to escape and returned to Paris. Meanwhile, in Grasse residents found a suspect who had claimed to be the real murderer and was sentenced to death by the Grasse government itself. Therefore, based on the writer's data and analysis above, the data is categorized as psychogenic needs-achievement need.

\section{CONCLUSION}

Based on the findings and discussion of the research, it can be concluded that this study examines the film Perfume: The Story of a Murderer by Patrick Süskind using the theory of Henry Murray the Psychogenic Needs. In this study, writers found 30 data consisting of as the need of acquisition, need of exhibition, the need of recognition, and need of achievement. result of this study and then analyzed according to existing data.

The conclusion of the entire analysis in this study is, writers have found that psychogenic needs as the ambition really exists in the main character in the movie Perfume: the story of murderer. This can be proven through:

Grenouille has a talent in smelling various scents since he is born then the talent bring him into ambition and strong obesity that Grenouille has to make a perfume to fulfill the talent owned by Grenouille, which is then 
categorized by writers into a psychogenic needs. And finally, the assessment process and morality felt by Grenouille in each data then categorized by writers into the psychological problems in him.

From the conclusion above the writer proposes to explain how the psychological analysis that is appears in Perfume: the story of a murderer movie based on the main character and used a psychological approach. But, through this research, there will be another or a future writer that also can do a research about speech act, but in a different theory, or using a different approach or the same approach, too.

\section{REFERENCES}

Endraswara, Suwardi. 2013. Metodologi Penelitian Sastra. Yogyakarta: CAPS (Center for Academic Publishing Service).

Minderop, Albertine. 2011. Psikologi Sastra. Jakarta: Yayasan Pustaka Obor Indonesia.

Munandar, S.C. Utami. 1985. Mengembangkan Bakat dan Kreativitas, (Jakarta: Gramedia).

Murray, Henry. 1938. Explorations in Personality: A Clinical and Experimental Study of Fifty Men of Collage Age. New York: Oxford University Press.

Perry, Vanessa G. dan Marlene D. Morris. (2005). Who Is in Control? The Role of Self-Perception, Knowledge, and Income in Explaining Consumer Financial Behavior. Retrieved from www.researchgate.net

Pickering, James H, dan Hoeper Jeffrey D. (1981). Concise Companion to Literature. New York: Macmillan Publising Co., Inc.

Pradopo, Rahmat Djoko. 1994. Prinsip-prinsip Kritik Sastra. Yogyakarta: Gadjah Mada University Press.

Welleck and Warren. 1993. Theory of Litearature.. New York: Harcort, Brace and Company.

Wijaya, Mangun WB. 1982. Sastra dan religiusitas. Jakarta: Sinar Harapan.

Wiyatmi. 2006. Pengantar Kajian Sastra. Yogyakarta: Pustaka. 